Research Article

\title{
Rodents' as Public Health Pests: Identification, Surveillance and its Management
}

\author{
SN Sharma, Ram Singh, Rina Kumawat, Sujeet Kumar Singh
}

National Centre for Disease Control, 22-Sham Nath Marg, Delhi, India.

DOI: https://doi.org/10.24321/0019.5138.201936

\section{I $\quad \mathbf{N} \quad \mathbf{F} \quad \mathbf{O}$}

\section{Corresponding Author:}

SN Sharma, National Centre for Disease Control,

22-Sham Nath Marg, Delhi, India.

E-mail Id:

drsns.nvbdcp@gmail.com

Orcid Id:

https://orcid.org/0000-0001-8569-1661

How to cite this article:

Sharma SN, Singh R, Kumawat R, Singh SK. Rodents' as Public Health Pests: Identification, Surveillance and its Management. J Commun Dis 2019; 51(4): 47-57.

Date of Submission: $2019-12-28$

Date of Acceptance: 2020-02-05

\section{$\begin{array}{llllllll}\mathbf{A} & \mathbf{B} & \mathbf{S} & \mathbf{T} & \mathbf{R} & \mathbf{A} & \mathbf{C} & \mathbf{T}\end{array}$}

Rodents' are considered as an important public health pest due to the carriers of $50 \%$ of zoonotic diseases in the animals. The zoonotic cycle with respect to plague, leptospirosis, scrub typhus, CCHF and KFD through rodents' has always been a matter of concern for the public health professionals. However, there is very little attention being made in the health department at the state level with regard to rodents" surveys, their identification and measures to be adopted for the prevention and management of rodents'. There is urgent need to have integrated rodents' management strategy in place as standard operating procedure in consultation of ministry of agriculture, animal husbandry and ministry of health \& family welfare. An attempt has been made in this manuscript to describe some of the important aspects of rodents' identifications, surveillance tools and tools available for the prevention and control of rodents' in rural and urban settings.

Keywords: Rodent, Public Health Pest, Zoonotic Disease

\section{Introduction}

A detail review on the rodents' as agricultural pest and species distribution has been well documented by Rao ${ }^{11}$, 12 during 2002 \& 2013. Ecology and control of rodents' of public health importance has been described by WHO in a report series during $1974 .{ }^{13}$

Globally, infectious diseases pose the most important cause of death. Among known human pathogenic diseases, approximately $50 \%$ are zoonoses. When considering emerging infectious diseases separately $73 \%$ currently belong to the group of zoonoses. ${ }^{1}$ Rodents', one of the important vertebrate pests (Advani \& Mathur, 1982) are directly related to the production and storage of crops and their utilization by man and livestock. ${ }^{2}$ It has been identified as the most important mammalian agricultural pests at the global level. ${ }^{3}$ The effect of rodent damage causes huge amount of crop losses and food shortages $s^{4-5}$ in some parts of the world. A large number of crops during pre and post harvesting periods are being lost every year. ${ }^{6}$ Among rodent pests, wild Indian house rat (Rattus rattus) is seriously active and a threat to the agricultural advancement in West Bengal, India. Observed $4.6-5.4 \%$ of rice and $11.9 \%$ of wheat is lost due to rodent damage in India. ${ }^{7-10}$

Rodentia is a largest order of Mammals in the world comprising 2,277 species in 481 genera under 33 families. Rodents' include squirrels, rats, mice, voles, gerbils, hamsters, dormices, porcupines etc. They are all mainly herbivores and their mode of feeding habits include gnawing, scraping or nibbling. They possess one pair of sharp, chisel-shaped incisors, in each of the upper and lower jaw. Molars are separated from the incisors by a long gap, Diastama. Canines are absent. Rodents' are economically important as some of them are serious pests destroying crops, fruit gardens, orchards, stored food grains. Moreover, they cause damages to the properties of various kinds resulting in huge economic losses. Some of them 
are carriers of serious diseases like Plague, Leptospirosis, Murine Typhus, etc.

\section{Classification}

- Class - Mammalia

- Order - Rodentia

- Family - Muridae

- Genus - Rattus and Mus

- $\quad$ Species - Rattus rattus (Roof rat), Rattus norvegicus (Norway rat) and Mus musculus (house mouse)

Rats are identified by their peculiar shape and arrangement of the teeth. They have no canine teeth but two pairs of strongly developed incisors (a pair on each jaw). Rats have diastema between the incisors and the molars. These 4 teeth (incisors) grow continuously throughout the life of the rats. The growth rate is reckoned to be around $13 \mathrm{~cm}$ per year. In order to keep them short and fit, the rats have to gnaw persistently any material in their access. If they do not do this, then their incisors would grow through their lips, exposing them to the risk of death. The gnawing capacity of the rats is remarkable. They gnaw and at the same time destroy wooden materials, wood floors, plastic materials, fabrics, bed mattresses, valuable cloths, skins and hides, crops, plants, grain in sack, electric wires etc. In fact, the presence of rats in premises may be detected by the finding of gnawed material. This gnawing habit makes the rats the most destructive enemy of humans.

\section{Distribution of Rodent Pests}

The distribution of rodent varies with the species. Some species are widely distributed while others are locally important. The lesser bandicoot rat is predominant in irrigated crop fields and grass lands throughout the country except in Indian desert, Lakshadweep and Andaman Islands. It has turned commensals and inhabits go downs and other premises in metropolitan cities.

The other species, which are widespread in both, irrigated and dry farming system in the country are the Indian gerbil, T. indica, Hie soft furred field rat, Millardia meltada and house mouse, Mus musculus. However, both T. indica and M. meltada have not been reported from Northeastern hill region. The Indian crested porcupine is widely distributed in South Asia in forest, rocky, moist and arid habitats.

Species with restricted distribution are the desert gerbil, Merione shurrianae and hairy footed gerbil, Gerbil/us gleadowi in the Indian desert; the Himalayan rat, $R$. nitidus in north eastern hill region; the short tailed bandicoot rat, Nesokia indica in north-western plains; the three striped palm squirrel in the southern peninsula and Western Ghat squirrel, F. tristriatus in the west coast of southern peninsula.

The house rat and house mouse are the major commensal pests. $R$. norvegicus is restricted mainly to ports. In the southern part of the country, $R$. rattus is a serious pest or orchards and in central India, it also occurs in rice, sugarcane and other field crops.

Eighteen species of rodents' are pests in agriculture, horticulture, forestry, animal and human dwellings and rural and urban storage facilities in India. Their habitat, distribution, abundance and economic significance varies in different crops, seasons and geographical regions of the country. Of these, Bandicota bengalensis is the most predominant and widespread pest of agriculture in wet and irrigated soils and has also established in houses and go downs in metropolitan cities like Bombay, Delhi and Calcutta. In dry land agriculture Tatera indica and Meriones hurrianae are the predominant rodent pests. Some species like Rattus meltada, Mus musculus and M. booduga occur in both wet and dry lands. Species like R. nitidus in north-eastern hill region and Gerbillus gleadowi in the Indian desert are important locally. The common commensal pests are Rattus rattus and $\mathrm{M}$. musculus throughout the country including the islands. R. rattus along with squirrels F. palmarum and F. tristriatus are serious pests of plantation crops such as coconut and oil palm in the southern peninsula. F. pennanti is abundant in orchards and gardens in the north and central plains and sub-mountain regions.

\section{Rodent Borne Diseases}

Rats are nearly omnivorous, but they would prefer grains if choice are possible. They are attracted to indiscriminately dumped garbage, carelessly exposed foods and other materials. They can travel a long distance in search of food and shelter from their breeding sites. Food intake of an average adult rat is estimated to be about 28 grams of dry food and about 15 to $25 \mathrm{ml}$ of water per day. They destroy far more than they consume. Some major identification of rodents' found in India is shown in Table 1 and Figure 1.

Detection of Rodent Infestation: The presence of rat in a given house can be detected by:

- $\quad$ Rat fecula (droppings): A fresh fecula is soft, moist and bright in colour while old fecula is dry, hard and fray to touch. Generally, the colour and size of rat fecula depends on what the rat has eaten and the type of rodent species respectively.

- Foot print and tail marks: For fresh fecula the foot print and tail mark is clean and greasy, whereas for old fecula it is old and dusty.

- $\quad$ Rat run ways: If a given area is infested by rats there exist a greasy marking on the pipe, beam, wire, floor, wall, rafter etc. Habitually rat follow the same run way between food, water, and harbourage.

- Distraction marks: Rat distract human properties like furniture, food, and clothing's due to their gnawing property. 
Table I.Rodent borne diseases

\begin{tabular}{|c|c|c|c|c|}
\hline S. No. & Rodent borne Diseases & Etiology & Reservoir & Vector \\
\hline 1. & $\begin{array}{c}\text { Venezuelan Equine } \\
\text { Encephalitis }\end{array}$ & $\begin{array}{c}\text { VEE Virus } \\
\text { (Gen.Alphavirus) }\end{array}$ & Rodents' & Aedes Spp. \\
\hline 2. & $\begin{array}{l}\text { Kyasanur Forest Disease } \\
\text { (KFD) }\end{array}$ & $\begin{array}{c}\text { KFD Virus } \\
\text { (Gen. Flavivirus) }\end{array}$ & Small Rodents' & $\begin{array}{l}\text { Ticks: Haemaphysalis } \\
\text { spinigera Ornithoros } \\
\text { Chiropterphila }\end{array}$ \\
\hline 3. & $\begin{array}{c}\text { Rocky Mountain Spotted } \\
\text { Fever }\end{array}$ & Rickettsia rickettsia & Domestic and wild rodents' & $\begin{array}{l}\text { Dermacentor } \\
\text { andersoni }\end{array}$ \\
\hline 4. & Boutonneuse Fever & $\begin{array}{c}\text { Rickettsia conori } \\
\text { Rickettsia sibirica } \\
\text { Rickettsia australis }\end{array}$ & Rattus spp. & - \\
\hline 5. & Scrub Typhus & $\begin{array}{c}\text { Rickettsia } \\
\text { tsutsugamushi }\end{array}$ & Rattus spp. & $\begin{array}{c}\text { Mite: Leptotrombidium } \\
\text { Spp. }\end{array}$ \\
\hline 6. & Chagas Disease & Trypnosomacruzi & Rodents' & Triatomabugs \\
\hline 7. & Cutaneous Leishmaniasis & Leishmania major & Merioneshurrianae & Phlebotomus salehi \\
\hline 8. & Plague & Yersinia pestis & $\begin{array}{c}\text { Tateraindica, } \\
\text { Bandicotabengalensis }\end{array}$ & $\begin{array}{l}\text { Xenopsylla cheopis } \\
\text { X.astia, X.brasiliensis }\end{array}$ \\
\hline 9. & Murine typhus & $\begin{array}{c}\text { Rickettsia } \\
\text { typhi(mooseri) }\end{array}$ & $\begin{array}{l}\text { Rattusnorvegicus } \\
\text { R.rattus, R.exulans }\end{array}$ & X.Cheopis \\
\hline 10. & Q Fever & Coxiellaburnetii & Rodents' & - \\
\hline 11. & Rickettsia Pox & Rickettsia akari & Musmusculus & $\begin{array}{l}\text { Mite: Liponyssoi- } \\
\text { dessanguineus }\end{array}$ \\
\hline 12. & $\begin{array}{c}\text { Argentine haemorrhagic } \\
\text { Fever }\end{array}$ & Junin Virus & $\begin{array}{c}\text { Rodents': } \\
\text { Calomysmusculinus } \\
\text { C.Laucha,Akodonazarae }\end{array}$ & - \\
\hline 13. & Colorado Tick Fever & Coltivirus & Rodents' & - \\
\hline 14. & Encephalo-myocarditis & EMC Virus & Rats and Mice & - \\
\hline 15. & $\begin{array}{l}\text { Fever caused by Gp. } \\
\text { CBunyaviruses }\end{array}$ & Bunyavirus & Wild rodents' & Culex.portesi \\
\hline 16. & Lassa fever & Arenavirus & $\begin{array}{c}\text { Rodents': } \\
\text { Mastomysnatalensis }\end{array}$ & - \\
\hline 17. & $\begin{array}{c}\text { Lymphocytic } \\
\text { Choriomeningitis } \\
\text { (Armstrong's disease) }\end{array}$ & Arenavirus & Musmusculus & - \\
\hline 18. & $\begin{array}{c}\text { Machupo Haemorrhagic } \\
\text { fever }\end{array}$ & Machupovirus & Rodents': Calomyscallosus & \\
\hline 19. & $\begin{array}{l}\text { OMSK Haemorrhagic } \\
\text { fever }\end{array}$ & OHF Virus & $\begin{array}{c}\text { Musk rat: } \\
\text { Ondatrazibethicus }\end{array}$ & - \\
\hline 20. & Tick borne Encephalitis & TBE Virus & Wild rodents' & - \\
\hline 21. & $\begin{array}{c}\text { Venezuelan } \\
\text { Haemorrhagic fever }\end{array}$ & Guanarito virus & $\begin{array}{l}\text { Cotton Rat: S.alstoni } \\
\text { Cane Mouse: } \\
\text { Zygodontomysbrevicanda }\end{array}$ & - \\
\hline
\end{tabular}




\begin{tabular}{|c|c|c|c|c|}
\hline 22. & $\begin{array}{c}\text { Venezuelan Equine } \\
\text { Encephalitis }\end{array}$ & VEE Virus & $\begin{array}{l}\text { Wild Rodents': } \\
\text { Sigmoden spp. } \\
\text { Prochimys spp. } \\
\text { Peromuscus spp. } \\
\text { Oryzomys spp. }\end{array}$ & $\begin{array}{l}\text { Culexaikenii } \\
\text { Cu.opisthopus } \\
\text { Cu.portesi }\end{array}$ \\
\hline 23. & Vesicular stomatitis & Vesiculovirus & Rodents' & $\begin{array}{c}\text { Midges, } \\
\text { Muscadomestica } \\
\text { (Mechanical carrier) }\end{array}$ \\
\hline 24. & Leptospirosis & Leptospirainterrogans & $\begin{array}{c}\text { Wild and Domestic rats } \\
\text { and Bandicoots } \\
\text { Rattusrattus, } R \text {. norvegicus, } \\
\text { Bandicotabengalensis }\end{array}$ & - \\
\hline 25. & $\begin{array}{c}\text { Angiostrogyliasis } \\
\text { A nematode disease of } \\
\text { the CNS }\end{array}$ & $\begin{array}{l}\text { Parastrongy- } \\
\text { Iuscantonensis }\end{array}$ & RattusandBandicotaSp & - \\
\hline
\end{tabular}

Table 2.Field identification of the major rodents' found in India

\begin{tabular}{|c|c|c|c|c|c|c|}
\hline Character & $\begin{array}{c}\text { Rattus } \\
\text { rattus } \\
\text { (Black rat) }\end{array}$ & $\begin{array}{c}\text { Rattus } \\
\text { norvegicus } \\
\text { (Brown rat) }\end{array}$ & $\begin{array}{l}\text { Mus musculus } \\
\text { (House } \\
\text { mouse) }\end{array}$ & $\begin{array}{c}\text { Bandicota } \\
\text { indica } \\
\text { (Greater } \\
\text { bandicoot rat) }\end{array}$ & $\begin{array}{c}\text { Bandicota } \\
\text { bengalensis } \\
\text { (Indian mole } \\
\text { rat) }\end{array}$ & $\begin{array}{c}\text { Suncus murinus } \\
\text { (Indian musk } \\
\text { Shrew) }\end{array}$ \\
\hline $\begin{array}{l}\text { Average } \\
\text { weight } \\
\text { (gms) }\end{array}$ & $8-12$ & 16 & 12 & 0.5 to 1000 & 350 & $23-147.3$ \\
\hline Fur & Black & brown & grey & $\begin{array}{l}\text { Dark brown to } \\
\text { almost black } \\
\text { in colour }\end{array}$ & $\begin{array}{l}\text { dark brown or } \\
\text { brownish gray } \\
\text { body fur, }\end{array}$ & $\begin{array}{c}\text { grey to almost } \\
\text { black }\end{array}$ \\
\hline Body & Slender & Heavy set & Small & Large & Large & Small \\
\hline $\begin{array}{c}\text { Muzzle } \\
\text { (mouth part, } \\
\text { nostril) }\end{array}$ & Pointed & Blunt & $\begin{array}{l}\text { Slender } \\
\text { (Sharp) }\end{array}$ & $\begin{array}{l}\text { Broad and } \\
\text { short }\end{array}$ & $\begin{array}{l}\text { Broad and } \\
\text { rounded }\end{array}$ & $\begin{array}{c}\text { Muzzle is narrow, } \\
\text { long and tapers } \\
\text { rostrally. }\end{array}$ \\
\hline Tail & $\begin{array}{l}\text { Longer than } \\
\text { body + head. }\end{array}$ & $\begin{array}{l}\text { Shorter } \\
\text { than body } \\
+ \text { head }\end{array}$ & $\begin{array}{l}\text { Equal to body } \\
\text { + head. }\end{array}$ & $\begin{array}{l}\text { Tail is shorter } \\
\text { than its head } \\
\text { uniformly } \\
\text { black in colour }\end{array}$ & $\begin{array}{l}\text { Tark tail is } \\
\text { shorter than } \\
\text { the head- } \\
\text { body length }\end{array}$ & $\begin{array}{c}\text { Thick at the } \\
\text { base and a bit } \\
\text { narrower at the } \\
\text { tip, }\end{array}$ \\
\hline Ears & $\begin{array}{l}\text { Large and } \\
\text { prominent. }\end{array}$ & $\begin{array}{c}\text { Small } \\
\text { closely set. }\end{array}$ & Very large & $30-40 \mathrm{~mm}$ & $\begin{array}{l}\text { pinkish in } \\
\text { shade, have } \\
18 \text { mammae }\end{array}$ & $\begin{array}{l}\text { small external } \\
\text { ears }\end{array}$ \\
\hline Feeding & Omnivorous & Same & Same & omnivorous & omnivorous & Insectivorous \\
\hline
\end{tabular}

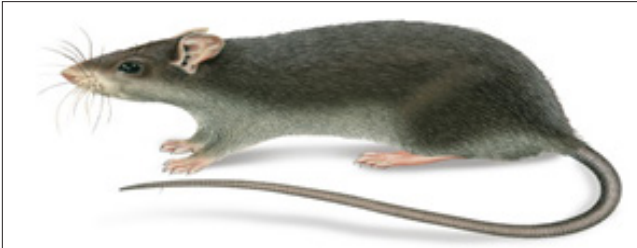

A. Rattus rattus
B. Rattus norvegicus 


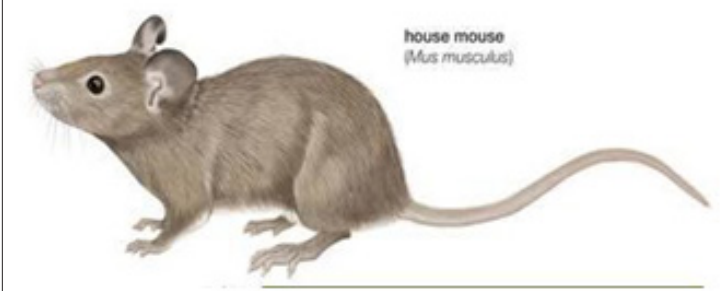

C. Mus musculus

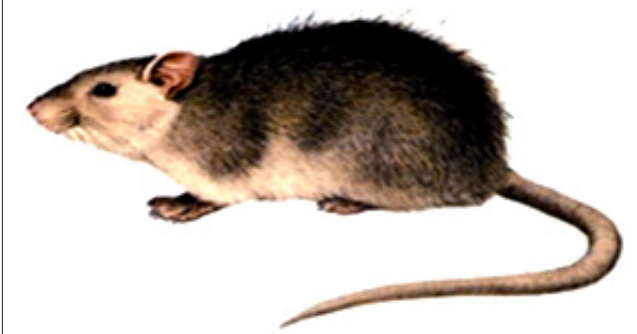

E. Bandicota bengalensis

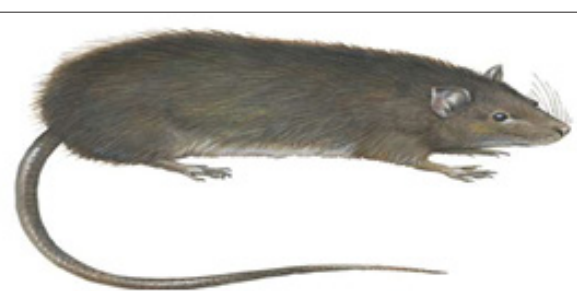

D. Bandicota indica

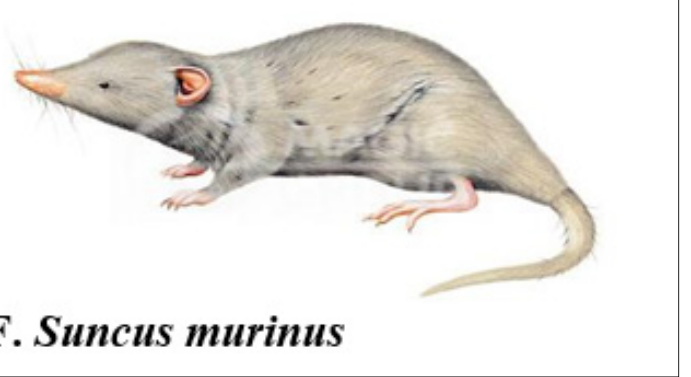

Figure I.Images (A-F) of major rodent species

Eighteen species of rodents' are pests in agriculture, horticulture, forestry, animal and human dwellings and rural and urban storage facilities in India. Their habitat, distribution, abundance and economic significance varies in different crops, seasons and geographical regions of the country. Of these, Bandicota bengalensis is the most predominant and widespread pest of agriculture in wet and irrigated soils and has also established in houses and godowns in metropolitan cities like Bombay, Delhi and Calcutta. In dryland agriculture Tatera indica and Meriones hurrianae are the predominant rodent pests. Some species like Rattus meltada, Mus musculus and M. booduga occur in both wet and dry lands. Species like R. nitidus in northeastern hill region and Gerbillus gleadowi in the Indian desert are important locally. The common commensal pests are Rattus rattus and $M$. musculus throughout the country including the islands. R.rattus along with squirrels Funambulus palmarum and F. tristriatus are serious pests of plantation crops such as coconut and oil palm in the southern peninsula. F. pennanti is abundant in orchards and gardens in the north and central plains and sub-mountain regions.

\section{Rodent Surveillance}

Most rodent surveillance is accomplished to determine rodent presence and infestation levels in warehouses, dwellings and similar structures.

Surveillance programmes that monitor disease activity in susceptible rodent populations alert public health authorities to increased human plague risks, thus allowing prevention and control programmes to be implemented before human cases occur. Surveillance in this case is usually done by visual survey for faeces, damage, rub marks and sightings of dead or live rodents', or sometimes with live traps, snap traps or glue boards. Commensal rodents' usually do not cause the problems in the field as they normally do at permanent installations, but other wild rodents' may become nuisances or serve as reservoirs of disease. Rodents', as well as their ectoparasites, occasionally must be collected to determine the presence of known, or perhaps new, vector-reservoir systems.

Rodent sampling techniques: The most common techniques for monitoring disease in rodent population include:

- Collecting and examining dead rodents'

- Monitoring activity among susceptible rodents'

- Trapping rodents' for population data, serum, tissue samples and ectoparasite collections

- Conducting sero-surveys of carnivore populations that consume rodents'

\section{Trapping Rodents}

Systematically trapping and examining rodents' is important to determine:

- The potential hosts in an area

- The number and kinds of fleas infesting these rodents'

- Whether new rodent species have entered an area

- Whether the abundance of resident rodent species has changed significantly since the previous trapping period

Trapping is also a source of basic population ecology data, including:

- Population densities (relative or absolute)

- Age structures and reproductive status of rodent populations

- Rodent habitat preferences and 4) local distribution

Estimates of absolute densities of rodent populations (number of animals present per unit area) can be made using Percent trap success; a relative density estimate is more easily obtained. This quantity refers to the number 
of animals caught per unit effort and equals the number of rodents' caught divided by the number of trapping periods, divided by the number of traps set per period, multiplied by 100 \{ (no. animals caught/no. trapping periods/no. trap sets per period) $\times 100=$ percent trap success.

The no. of rodents' trapped is evaluated in terms of trap positivity rate which represents the average no. of small mammals captured per traps set and may be calculated by the formula given below:

$$
\text { Trap positivity rate }=\frac{\text { No of traps positive for rodents' }}{\text { No of traps laid }}
$$

Snap traps can be used, but must be emptied almost immediately after the animal is captured. Snap traps work better if the triggers are "expanded" with hardware cloth, thin metal, etc. At sunrise or sunset, set 50 to 100 traps in a line in areas where rodents' are active. Areas such as fence lines, along paths, where a wooded area meets a grassy area, etc., are ideal. Bait the traps with chewed oatmeal, peanut butter, or other useful bait, and place the traps five to ten feet apart as rapidly as possible. As soon as the last trap is set go back to the first trap and start picking up the traps. If rodents' are caught, put each rodent and the trap that caught it in a separate ziplock bag to make sure parasites remain associated with their hosts. Speed is essential because fleas will leave a dead host as soon as its body temperature drops two or three degrees.
Live capture traps of several varieties are effective in trapping rodents' for ecto-parasite surveys. These do not kill the rodent so immediate pickup is not as essential. They may be set in the evening and collected the next morning. If Sherman or similar solid-wall traps are used, they must be picked up very early in the morning or the sun will raise the temperature within the trap to levels lethal to the rodent, and ecto-parasites will leave. As with snap traps, live capture traps with their contained rodent should be placed in individual ziplock bags so ecto-parasites will not be separated from their hosts. When returned to the laboratory, rodents' must be euthanized (if living) and their ecto-parasites removed. If identification of rodents' in the field is impossible or impractical, the rodent should be prepared so it can be identified by an authority on rodents' (Figure 2 ).

When the rodent is dead, remove it from the trap and check the trap and killing chamber for ecto-parasites, which will also be dead. Place any parasites found in a vial of alcohol. Then the rodents' must be processed in one of two ways to remove their parasites. Use a nit comb or small, stiffbristled brush to vigorously brush the rodent, against the grain of the hair, into a white enamel cake pan or similar container. The ecto-parasites will be brushed out of the hair and into the cake pan. Remove them and store in a vial of alcohol, along with any ecto-parasites that were removed from the ziplock bag, trap and killing chamber.

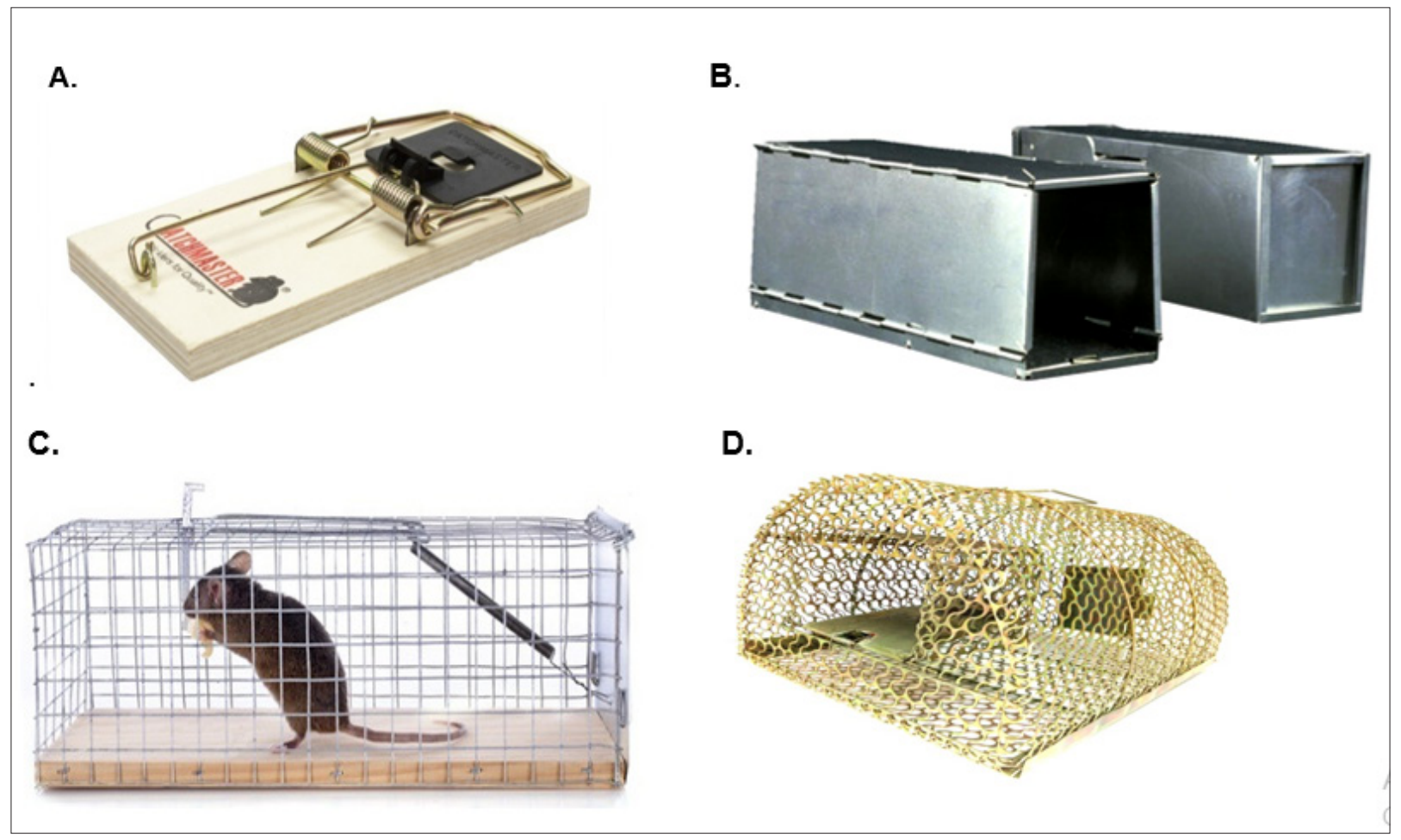

Figure 2.Images of different types of traps used in Rodent survey as A. Snap trap B. Sherman trap, C. Live trap and D. Multiple trap 
Cattle and Buffaloes are known to be the among the principal hosts of tick vectors of KFD. Small mammals such as various species of rodents' and insectivores including Rattus rattus wroughtoni, Rattus rattus rufescens, Rattus blanfordi, Funambulustristriatus, Ratufaindica, Petauristaphilipinensis, Suscus murinus etc.are important host particularly for immature stages.

Small mammals can be held in a wire cage mesh cage placed over a tray of water, so that the fully engorged ticks drop into water from where they can be picked up without damage. The engorged tick can be held until they moult into next instar. The later instars are easier to identify as compared with the earlier ones.

The density of tick infestation on a host species is evaluated in terms of tick index, which represents the average number of ticks per host individual examined and may be calculated by the following formula.

$$
\text { Tick Index }=\frac{\text { Total number of ticks collected }}{-\mathrm{T}}
$$

\section{Rodent Management}

The process involves managing rats and mice to below tolerable levels using different control methods, viz., preventive, curative, environmental sanitation etc.

Rodent Management need to undertake in a comprehensive package of integrated tools which can based on the its varied habitats/ ecology and the control measures should be targeted on proper translation of ecological factors into management planning. The main objective of rodent management should be bringing down the damage caused by them rather than to kill the pest. Use of chemicals to kill the rodents' pests should be undertaken as last resort. It is important to take account of spatial distribution of the pest. It is opined by common man that rodent management can be achieved as physical killing, which is not true. However, It is by putting a strategy by manipulating their behaviour to avoid them as pests causing harm for commodity loss or transmission of diseases to humans and livestock including poultry.

\section{Strategies for Rodent Management}

The rodent management can be divided broadly into two main strategies.

1. Preventive

2. Curative

1. Preventive Measures

- Cultural Control: Habitat Manipulation and Rodent Proofing of the yard, Clean cultivation etc

- Ultra-sonic devices

- Chemical Repellants

\section{Curative Control}

- Physical/ Mechanical

- Biological Methods

- Chemical methods

\section{Preventive Rodent Pest Management in Field}

Rodent management is a very complicated problem. It needs a thorough approach to minimize the rat menace. Before planning we should know some facts about rats.

- It has been noticed that the rats restrict their activity within 5-10-meter radius around the burrow.

- Methods of killing rats are effective only when carried out on a large scale, covering large contiguous areas and are repeated time and again. The aim should be to kill more than 90 per cent of the population otherwise they breed so fast that population reaches the same level within a few months.

- The migration of rats from one place to other is also important to born in mind while planning to manage rat population. The cooperative efforts made by the farmers, grain handlers and administrators will not provide protection unless as a scheduled programming is done with a system approach.

\section{Prevention of Reproduction Bouncing}

Rodents' exhibit two types of reproductive features based on habitat sustenance.

- In a stable or seasonally predictable environment will have limited population (stable or $k$-selected) due to the limited availability of food and other resources.

- The growth is logistic with litter sizes between 6 to 8 young ones per female (as in figure) due to constant availability of food, water, and harbourage.

The population size depends on density dependent factors such as competition for food or nesting sites. However, when more food and harbourage become available (through uncleared garbage and killing part population), the residual rodent population bounces produce more young ones irrupting the population or $r$ selected with a slow start and accelerating to a litter size of up to 20 young ones per female (as in figure). Environmental events like flash floods also lead to similar results. Hence, while planning this major aspect of reproductive bouncing needs to be considered.

\section{Rural Settings \\ Cultural Control}

Habitat Management

- Cultural Control like Ring Weeding, Cleaning practices prevent the rodents' to establish their habitat.

- Deep Ploughing: Frequent Deep plowing and harrowing drives away rodents' from their nesting place and inhibit the breeding. It destroys the burrows and helps 
in migration of rodents' from fields.

- Reduction in Bund Size $(<30 \mathrm{~cm})$ : Discourages the rodents' to burrow.

- Cultivation of Non-Preferred Crops: Guar, castor etc. may be taken as strip crop (10 m).

- Cultivation of Non-Preferred crops: Guar, castor etc. may be taken as strip crop (10 m).

- Weed Control: Weeds provide food and shelter. Regular weed control practices may minimize the rodent infestation considerably.

- Burning/ Removal of wild vegetation \& refuge of pervious crops.

○ Grazing

- Irrigation

- Trap barrier System may be employed in rice farming as fencing and for fixing traps

Proper water management will play a greater role in checking the rat population.

\section{Rodent Proofing the Yard}

\section{Eliminate Food Sources}

- Prevent rodent entry and proofing

- Remove defective refuse cans

- Provide a sufficient amount of refuse cans. A 32-gallon container with a tight fitting lit is best

- Regular garbage collection and disposal may be ensured

- Drain and wrap garbage before disposing

- Remove pet food immediately and clean up animal

2. Eliminate Water

- Keep all drains covered and secure

- Make sure hoses are not leaking

- Get rid of any standing water in yard

- Fix any defective pipes or drains

3. Eliminate Rodent Hiding Places

- Get rid of junk, lumber, old boxes, discarded appliances chairs or bedding on the ground or under porches

- Remove abandoned vehicles

Rat Repellant

- $\quad$ Rattlers are erected at different points in the field to keep away nocturnal rats, mice and porcupines. For this a bamboo pole of about 2-3 meters in length is erected firmly on the ground

- Neem leaf powder (5\%) showed anti feedant action on rodents

- Neem oil repelled the rats to the tune of $18-48 \%$.

- Botanicals like kaner seeds, neem cake, castor seeds and jatropha seeds showed anti rodent properties in preliminary trials

- Crude cotton-seed oil (5\%) showed anti fertility effects on bandicoots

\section{Repelling House Mouse/ House Rat}

Rats are easily repelled by certain smells. Effective smells are of their natural predators, such as cats. Peppermint oil / cedar leaf oil have been shown to deter rats for up to a few days. Naphthalene balls in places of rat activity will make the area rat free.

\section{Ultrasonic Devices}

- Ultrasonic sonic devices put the stress to rodents'. Ultrasonic rodent repellers emit high frequency ultrasound waves to create an acoustically hostile environment that repels rodents', over the long period. Kinder than traps, safer than poisons, and inaudible to people and non-rodent pets.

- The principal of ultrasonic devices is to create a loud noise above the range of human hearing (above18-20 $\mathrm{kHz}$ ) that is unpleasant to pest species.

- The problems with ultrasound are numerous. Animals can adapt to most situations, and in a short amount of time they become familiar to the sound.

\section{Chemical Repellent}

- Lauronitrite, actidione, Denatonium benzoate (10ppm), Neem, kaner, Jojoba and malathion are some of the reported repellents

- A repellent called R-55 (Rodaban) has been developed recently in USA

\section{Chemosterilants}

Chemical of plant origin: Alpha cclorohydrin (chemical) Gossypol, crude cotton seed oil and Glycosides of Trypataregiumwilfordi show potential as antifertility compounds.

Chemicals which make the rat sterile are Furadantine $0.02 \mathrm{~g}$ and colchicine $0.14 \mathrm{~g}$. These are generally used as mixture of one tablet of furadantine and half tablet of colchicine in the wheat flour to make both sexes sterile.

\section{Urban Settings}

\section{Curative Control}

\section{Mechanical Control}

- Trapping may be an effective tool for field rodent management in limited areas, like threshing yards where application of poisons is not possible

- It is extremely useful for management of residual pest population surviving after poison baiting

- It is essentially required for identification, survey and monitoring of the pest species

\section{Traps}

\section{Type of Traps}

Traps can be used in situations where poisons are not allowed or recommended. 
- Pit Fall Traps: Cow dung slurry/ baits etc

- Dead Fall Traps

- Snares: Used in coconut trees

- Cage Traps/Wonder Traps: Multiple catch trap, baiting required. For bandicoot it is not effective but for social rats

- Sherman Traps/Box Traps

- Glue board Traps: Disposable type. Very easy to in any situation, indoors-offices, restaurants, hotels, ships, railways (pantry cars)

- Snap Traps

- Bow Traps

- Box Traps

- Nets

\section{Use of Traps to Tackle Urban Rodent Infestations}

Various types of traps are available in market to tackle urban rodents', viz., non-poisonous sticky traps, kill type snap traps and live traps (wonder traps).

\section{Nonpoisonous Sticky (Glue) Boards}

- These are 'ready-to-use glue boards' with the boards coated with poly butane (sticky substance) to remove local infestations.

- Their usage is discouraged by Ministry of Environment and Forests on humane aspects.

- They will not be affective in public places due to dust or moisture.

- Check these traps frequently and dispose of rodents' humanely.

\section{Snap (kill) Traps}

- $\quad$ Snap traps in various types and sizes are available in market

- They are effective in killing rodents' at low infestation levels

- Set the traps on rodent runways during their activity period i.e., night time

- Remove the dead rodent at the earliest from the trap

- Clean the traps with water once a rodent is trapped

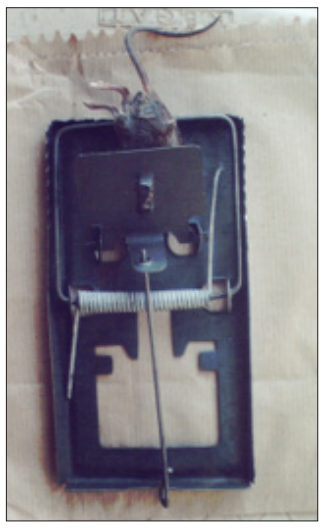

Figure 3

\section{Cage (live) Traps}

- Use these traps to trap rats and mice in isolated and low-level infestation situations

- Don't release the trapped rats outside the premises, which makes them to reach back.

- Wash them thoroughly before next use to remove any warning pheromone deposited on the trap

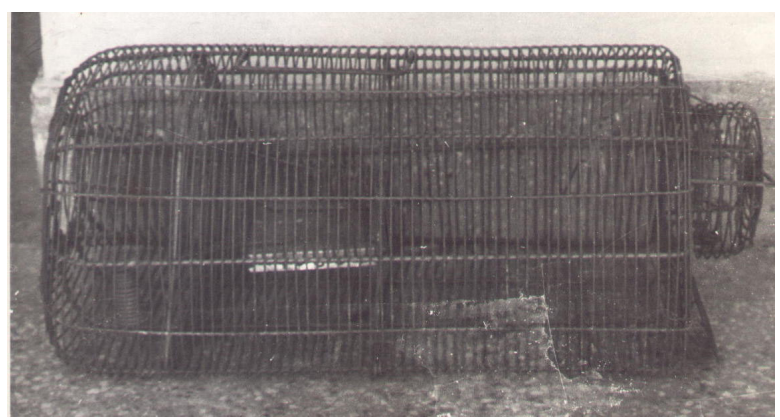

Figure 4

- The trapping of rodent pests is often preferable to the use of poisons.

- Traps prevent rodents' from dying in inaccessible places and causing an odor problem.

- There is no chance of an accidental poisoning or secondary poisoning of non-target animals.

\section{Poison Baiting}

Use of rodenticides is common practice in local bodies as well as in premises. Although seven rodenticides are registered under the Insecticides Act, 1976, only zinc phosphide and bromadiolone are available in market. Aluminum phosphide is available with restricted legal provisions.

\section{Rodenticides}

\section{- Zinc Phosphide}

- It is an acute inorganic rodenticide

- It is recommended for use at $2 \%$ in cereal baits using vegetable oil as binding medium

- These baits release phosphine gas in the acidic medium of stomachs of rodents' on eating the baits

- It detoxifies rapidly in dead rats and baits and thus is relatively safer for use and economical

- It gives an overall rodent control success of about $60 \%$.

- It has no effective antidote

- It is recommended to be used in open urban areas like parks, rail tracks etc

- $\quad$ Extreme care needs to be taken to safeguard non-target species like dogs, cats in the habitations

\section{Bromadiolone}

- It is a second-generation anticoagulant

- It is recommended under IPM packages for rodent 
control in storage/domestic premises

- It is used in cereal bait formulation with wax coating at $0.005 \%$ a.i., (ready-to-use formulation) and applied inside closed containers (bait stations) or applied inside burrows@ one piece/ burrow

- Bait shyness does not exist with this chemical

- $\quad$ Repeat application might be required based on residual rodent infestation

\section{Aluminum Phosphide}

- It is a burrow fumigant can be used in public places and around the premises for effective control of burrow dwelling rodents' i.e., bandicoots

- Due to easy handling, application and immediate kill of the rats inside the burrows, the fumigant is preferred, in spite of lethal toxicity in accidental handling

- The burrow fumigation inside the premises must be avoided due to hazard of accidental poisoning

\section{Bait Delivery Methods}

The method of application of baits depend on the situation - open areas in the urban areas or inside the premises of various establishments as given below:

\section{Open/ Public Areas}

\section{Packeting and Pocketing}

- $\quad$ Prepare the poison bait (bromadiolone ' $C$ ' at $0.005 \%$ a.i.) using bait base like broken grain adding binding medium - vegetable oil. Make them in to small packets of $20 \mathrm{~g}$. using newspapers

- $\quad$ Place each packet $3 \mathrm{~cm}$. deep inside each active rodent burrow. This will prevent any accidental poisoning

- Examine for residual rodent infestation, if any, after a fortnight

- Treat the reopened burrows

\section{Permanent Bait Stations}

Construct permanent bait stations made of cement structures should be constructed in public places like parks, shopping malls, drainage canals, road side culverts etc. The bottom opening should be only $3 \mathrm{~cm}$. such small opening prevent entry of granivorous birds and other non-target species.

- They afford protection to non-target animals and children

- $\quad$ Prepare the anticoagulant baits as in above step

- Place $100 \mathrm{~g}$ of the bait inside the bait station from the top hole and keep a lid to it

- Examine these permanent bait stations once in 15 days and replenish the anticoagulant bait on complete consumption

\section{Conclusion}

A comprehensive strategy as integrated rodent management has been worked out for localised pest management. It can be concluded that rodents' are not only agricultural pests but also act as public health pests responsible in the transmission of many diseases to the human beings. Safeguards and measures for the prevention and control of rodents' in urban and rural settings is essential to prevent the deadly diseases like plague, leptospirosis, scrub typhus, CCHF and KFD. It is desirable that a Standard Operating Procedure (SPO) may be prepared by the ministries of agriculture, urban development, local bodies, railways in consultation with health with its area specific implementation at the grassroot level.

\section{Conflict of Interest: None}

\section{References}

1. Prasad VR. Rodents' Control in India. Integrated Pest Management Reviews 1999; 4: 97-126. Available from: http://projects.nri.org/bandicoot/docs/rodent_ control_in_india.pdf [Google Scholar].

2. Advani CR, Mathur RP. Experimental reduction of rodent damage to vegetable crops in Indian villages. Agroecosyst 1982; 8(1): 39-45. Available from: https://www.sciencedirect.com/science/article/abs/ pii/0304374682900130 [Google Scholar].

3. Cuong LQ, Chien HV, Han LV, Duc VH, Singleton GR. Relationship between rodent damage and yield loss in rice in Mekong Delta, Vietnam. Rats, mice and people; Rodent Biology and Management (Singleton GR, Hinds LA, Kebs CJ, et al. eds., Australian Center for International Agricultural Research. Canberra. 2002; 217-219. Available from: https://www.researchgate.net/profile/ Rhodes_Makundi/publication/260025210_Interaction_ between_rodent_species_in_agro-forestry_habitats_ in_the_western_Usambara_mountains_northeast_ Tanzania_and_its_potential_for_plague_transmission_ to_humans/links/0046352f2125b7eeee000000. pdf\#page $=291$ [Google Scholar].

4. Fayenuwo JO, Olakojo SA, Akande M, Amusa NA, Olujimi OA. Comparative Evaluation of vertebrate pest damage on some newly developed quality protein maize (QPM) varieties in south western Nigeria. Afri J Agri Res 2007; 2(11): 592-595. Available from: http:// www.academicjournals.org/app/webroot/article/ article1380898507_Fayenuwo\%20et\%20al.pdf [Google Scholar].

5. Amusa NA, Iken JE, Fyenuwo JO. The incidences of field diseases and vertebrate pest on popcorn (Zea mays everta) varieties cultivated in agro forest ecologies in Nigeria. World J of Agric Sci 2005; 1(2): 173-177. Available from: https://pdfs.semanticscholar.org/ c3db/9c90a1a5a22231f9de86da02b7610e434d99. pdf [Google Scholar].

6. Meerburg BG, Brom FWA, Kijlstra A. The ethics of rodent 
control. Pest Management Science 2008; 64(12): 12051211. Available from: https://onlinelibrary.wiley.com/ doi/abs/10.1002/ps.1623 [PubMed/Google Scholar].

7. Tripathi RS, Sahu BK, Sahoo G. Integrated Rodent Pest Management in Field and Stores. 2017. Available from: orienvis.nic.in/indexx.aspx?langid=1\&slid $=1073 \&$ mid $=2 \&$ sublinkid $=342$.

8. Barnett SA, Prakash I. Rodents' of economic importance in India. Arnold Heinemann Publ. New Delhi, India. 1975; 175-185. Available from: http://agris.fao.org/ agris-search/search.do? recordID=US201300533655 [Google Scholar].

9. Chakraborty R, Chakraborty S. Food habits of larger bandicoot rat, Bandicota indica (Bechstein) in the fields of west Bengal during rainy season. Rodent News/ 1982; 6: 27-30. [Google Scholar].

10. Singh D, Bhanja, SK, Rao AMKM. Rodent pest management in poultry farm, feed and hatchery. Project Directorate on Poultry, Hyderabad. Technical Bulletin 2012; 1-12. [Google Scholar].

11. Rao AMKM. Integrated rodent pest management. In: Rodents' in Indian Agriculture (Prakash, I and Ghosh, P.K. Ed.), Scientific Publishers, Jodhpur. 1992; 651-658.

12. Rao AMKM. Rodent problems in India and strategies for their management. Rats, Mice and People: Rodent Biology and Management (Eds. Singleton, GR., Krebs, CJ and Spratt, DM), ACIAR, Canberra. 2003; 229-232. Available from: https://www.academia.edu/36203941/ Rodent_problems_in_India_and_Strategies_for_their_ management.

13. WHO. Ecology and control of rodents' of public health importance: Report of a WHO Scientific group. WHO Technical Report Series 553, Geneva. 1974; 1-42. Available from: https://lib.ugent.be/en/catalog/rug 01:002327055. 